\title{
The effects of different mechanical detasseling methods on hybrid maize seed production
}

\author{
L.B.O. Costa $^{1}$, I.R. Carvalho ${ }^{2}$, L.L. Ferreira ${ }^{3}$, V.J. Szareski ${ }^{1}$, \\ J.R. Pimentel ${ }^{1}$, C. Troyjack ${ }^{1}$, M.H. Barbosa ${ }^{1}$, J.A.G. Da Silva ${ }^{2}$, \\ G.G. Conte ${ }^{1}$, F.A. Villela ${ }^{1}$, T. Pedó ${ }^{1}$ and T.Z. Aumonde ${ }^{1}$ \\ ${ }^{1}$ Universidade Federal de Pelotas, Capão do Leão, RS, Brasil \\ ${ }^{2}$ Universidade Regional do Noroeste do Rio Grande do Sul, RS, Brasil \\ ${ }^{3}$ Centro Universitário de Mineiros, Mineiros, GO, Brasil
}

Corresponding author: I.R. Carvalho

E-mail: carvalho.irc@gmail.com

Genet. Mol. Res. 18 (4): gmr18207

Received November 13, 2018

Accepted August 07, 2019

Published October 30, 2019

DOI http://dx.doi.org/10.4238/gmr18207

\begin{abstract}
We evaluated the efficiency of three mechanical detasseling methods on the production of hybrid maize seeds. The experiment was run in the crop season of 2016/2017 in Indianópolis, MG, Brazil. The design used was random blocks, where the treatments corresponded to three detasseling methods: Puller (PUL) based on only one mechanical detasseling operation, Cutter $2 \mathrm{x}+$ Puller (C1P) - based on two mechanical detasseling operations by the Cutter method and one operation by the Puller method, and Cutter + Puller (C2P) - based on only one operation by the Cutter method and one operation by Puller. There was variability in the effects and efficiency of the mechanical detasseling methods in the production of hybrid maize seeds. The two methods $\mathrm{C} 1 \mathrm{P}$ and $\mathrm{C} 2 \mathrm{P}$ had small differences; both being superior to PUL. The mechanical detasseling method based on one operation of Cutter and one operation by Puller method is recommended, since it minimizes costs, lowering transfer and genetic contamination as well, and it optimizes the production of hybrid maize seeds per plant and unit area.
\end{abstract}

Key words: Zea mays; Production hybrid seed; Optimization of operations 


\section{INTRODUCTION}

The maize plant (Zea mays) belongs to the Poaceae family, and it is one of the main cultivated species in the world. It presents elevated agricultural demand, and its use is destined as much for animal as for human consumption (Carvalho et al., 2017; Szareski et al., 2018). In Brazil, for the 2016/2017 crop season, the total area cultivated with maize was approximately 17 million hectares, and the production was superior to 97 million tons of grains (Conab, 2017).

The crescent increase in maize yield is linked to new management techniques and technologies employed in its cultivation. It includes the use of more adapted genotypes, hybrids with high productive potential, resistance or tolerance to diseases or pests, use of biotechnological tools for the technology transference by high quality seeds, where the rate of seeds usage in Brazil is approximately 90\% (Abrasem, 2018).

The process of maize hybridization consists on a method that eliminates the male inflorescence (tassel) of the genitor female plants, with the objective of favor the intra-specific cross benefiting from the anemophily effects (Nardino et al., 2016; Uitzil et al., 2016). The detasseling process or tassel removal must be realized before the pollen liberation, in order to minimize the endogamy effects and proportionate the benefic effects of the heterosis or hybrid vigor, as well, of seeds contamination. The period of presumable flowering can be estimated based on information of sowing season, edaphoclimatic conditions (air temperature) and response of thermal summation.

The emasculation or detasseling process demands plenty qualified labor, since it can occur the pollen liberation concomitant to the stigmas exposition in the ear of the female genitor. In this manner, there is the necessity of daily accompany the field of seeds production during the maize flowering, as well, look to maximize the genetic and physiologic quality of the produced seeds (Baretta et al., 2017; Nardino et al., 2018). In this manner, seeking the reduction of labor, most of detasseling operations in high scale are mechanical, being done with the aid of a machine known as "Hagie". The exceptions are when there is difficult to enter in the field to operate the machine, in this case a manual process is used (Magalhães et al., 1999; Pereira, 2007).

In this way, many production fields of hybrid maize utilize this methods, but it use can result in stresses in the plants development due to the loss of top leaves, which culminates in reduction of seeds yield per plant (Komatuda et al., 2006; Carvalho et al., 2016; Nardino et al., 2016). In this manner, this work aimed the evaluation of the efficiency of three mechanical detasseling methods in the production of maize hybrid seeds.

\section{MATERIAL AND METHODS}

The experiment was fun in the crop season of 2016/17 in Indianópolis - MG, Brazil. Located at latitude $18^{\circ} 58^{\prime} 35,12^{\prime \prime}$ South and longitude $47^{\circ} 48^{\prime}$ 52,71" West, and altitude 970 meters. The sowing in the field occurred in October 2016. The field organization was based on the sowing of four rows of the maternal inbreeding line (pollen receptor) and two rows of the paternal line (pollen donor).

The design used was random blocks, where the treats corresponded to detasseling methods; PUL: denominated from "Puller" based on only one mechanical detasseling operation; C1P: denominated from "Cutter 2x + Puller", based in two mechanical detasseling operation by the "Cutter" method and one operation by the "Puller" method; C2P: denominated from "Cutter + Puller" being based on only one operation by "Cutter" method and one operation by "Puller" 
method (Figure 1), disposed in eight repetitions. The efficiency of different mechanical detasseling methods was evaluated in relation to the following characters:

Number of leaves above ear (NLE), measured through the magnitude of reminiscent leaves in the plant after the mechanical detasseling methods were applied. Results in units.

Humidity of seeds at harvest (HSH), measured through the kiln method (RAS, 2009). Results in percentage.

Humidity of seeds after drying (HSD), measured through the kiln method (RAS, 2009). Results in percentage.

Mass of ears harvested at production field (MEF), measured the mass of ears at the production field. Results in $\mathrm{kg}$. in $\mathrm{kg} .1$

Mass of ears after drying (MED), measured the ears mass submitted to drying. Results

Thrashing yield (TY), the ratio between seeds mass and dry ears mass. Results in percentage.

Mass of thrashed seeds (MTS), measured the mass of clean seeds after thrashing. Results in $\mathrm{kg}$.

Seeds yield at pre-cleaning (SYC), the ratio between the mass of clean seeds and the mass of seeds with impurities. Results in percentage.

Seeds cleaned for classification (SCC), obtained through the mass of clean seeds. Results in kg.

Thousand seeds mass (TSM), measured through the methodology proposed by the Rules for Seeds Analysis (RAS, 2009). Results in grams.
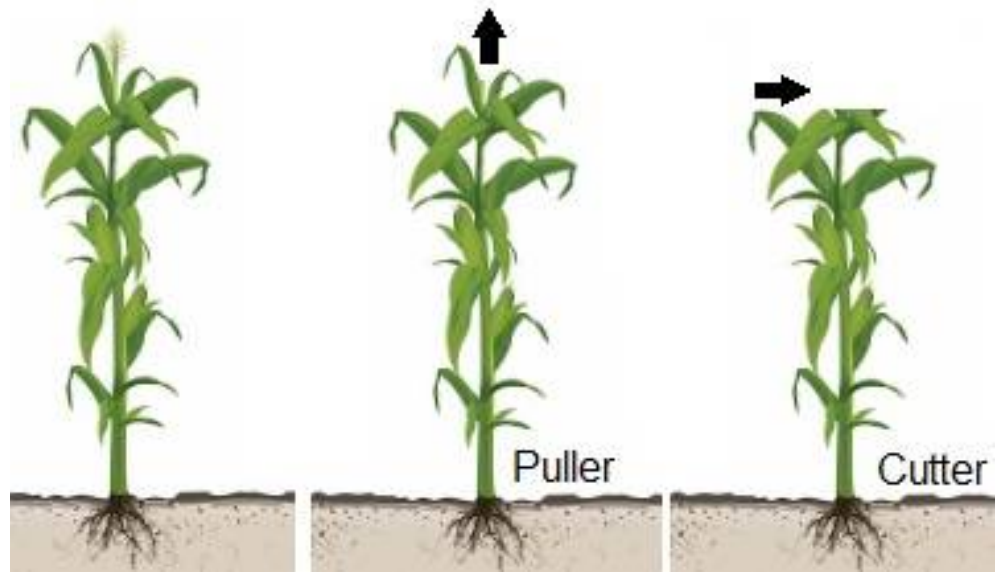

Figure 1. Schematic demonstration of mechanical detasseling methods in maize.

The obtained data was submitted to presupposition diagnosis, where it was verified the normality and homogeneity of residual variances and additivity of the statistical model. Afterwards, it was realized the variance analysis at 5\% of probability, and verifying variability for the aimed characters, it was proceeded the complementary analysis by Tukey at 5\% probability. These characters were submitted to general linear correlation for all treats, with the purpose of identify the associations tendency among characters and built a casual diagram. The significant characters were submitted to Mahalanobis algorithm, and then, constructed the matrix of genetics distances in order to apply the method of relative contribution of Singh (1981), and the main Biplot compounds, weighted by the residual variances matrix. 


\section{RESULTS AND DISCUSSION}

The variance analysis revealed significance of $5 \%$ probability for the characters (Table1), NLE, MEF, MED, TY, MTS, SYC and SCC. For the character NLE the C2P detasseling method was superior over the PUL detasseling method, being more harmful to maize plants where the photosynthetic active foliar area was minimized. For the characters MEF, MED, SYC, SCC it was verified superiority for the method Cutter $2 \mathrm{x}+$ Puller. It was checked because when executing two operations of mechanical detasseling with Cutter and one with Puler, there was an increment in the main production attributes of maize seeds, as well, potentiated the logistic of receiving and benefitting seeds (Table 2).

Table 1. Variance analysis summary for the characters in relation to the mechanical detasseling methods applied in the production of hybrid maize seeds.

\begin{tabular}{|c|c|c|c|c|c|c|c|c|c|c|c|}
\hline SV & DF & NLE & HSH & HSD & MEF & MED & $\begin{array}{c}\text { TY } \\
\text { MS }\end{array}$ & MTS & SYC & SCC & TSM \\
\hline $\begin{array}{l}\text { Detasseling } \\
\text { Methods }\end{array}$ & 2 & $2.728^{*}$ & 0.015 & 0.011 & $14405953.17^{*}$ & $9921781.2 *$ & $0.0004 *$ & $2511849.0^{*}$ & $0.00167917^{*}$ & $2231085.75^{*}$ & 0.041 \\
\hline Blocks & 7 & 0.001 & 1.411 & 0.035 & 3759641.14 & 1171303.0 & 0.00007 & 224914.3 & 0.00008036 & 117281.77 & 10.755 \\
\hline Residue & 14 & 0.004 & 0.379 & 0.037 & 2507566.50 & 892209.62 & 0.00008 & 180814.2 & 0.00014107 & 98286.79 & 11.613 \\
\hline $\mathrm{CV}(\%)$ & 23 & 2.92 & 2.29 & 1.85 & 8.09 & 5.94 & 2.04 & 6.05 & 1.51 & 5.70 & 1.23 \\
\hline
\end{tabular}

*Number of leaves above ear (NLE), Humidity of seeds at harvest (HSH), Humidity of seeds after drying (HSD), Mass of ears harvested at production field (MEF), Mass of ears after drying (MED), Thrashing yield (TY), Mass of thrashed seeds (MTS), Seeds yield at pre-cleaning (SYC), Seeds cleaned for classification (SCC), Thousand seeds mass (TSM).

Table 2. Means for the effect of mechanical detasseling methods applied to the production of hybrid maize seeds.

\begin{tabular}{llllllll}
\hline Detasseling methods & NLE & MEF & MED & TY & MTS & SYC & SCC \\
\hline PUL & $1.57 \mathrm{c}^{*}$ & $18225.0 \mathrm{~b}$ & $14605.0 \mathrm{~b}$ & $0.437 \mathrm{~b}$ & $6388.1 \mathrm{~b}$ & $0.766 \mathrm{~b}$ & $4896.8 \mathrm{~b}$ \\
C2P & $2.64 \mathrm{a}$ & $20908.8 \mathrm{a}$ & $16818.6 \mathrm{a}$ & $0.446 \mathrm{ab}$ & $7459.7 \mathrm{a}$ & $0.792 \mathrm{a}$ & $5899.5 \mathrm{a}$ \\
C1P & $2.51 \mathrm{~b}$ & $19548.3 \mathrm{ba}$ & $15925.3 \mathrm{a}$ & $0.452 \mathrm{a}$ & $7207.7 \mathrm{a}$ & $0.790 \mathrm{a}$ & $5685.3 \mathrm{a}$ \\
CV $(\%)$ & 2.93 & 8.09 & 5.98 & 2.04 & 6.06 & 1.52 & 5.71 \\
\hline
\end{tabular}

${ }^{*}$ Means followed by same lowercase letter in the column do not statistically differ by Tukey at 5\% probability. **Number of leaves above ear (NLE), Mass of ears harvested at production field (MEF), Mass of ears after drying (MED), Thrashing yield (TY), Mass of thrashed seeds (MTS), Seeds yield at pre-cleaning (SYC), Seeds cleaned for classification (SCC), Thousand seeds mass (TSM).

Although, considering management costs and labor time, the minimal difference found between $\mathrm{C} 1 \mathrm{P}$ and $\mathrm{C} 2 \mathrm{P}$ indicates that the last one would be a better call, even though this was not found by Sanger and Salvador (1998), where no enhancing was observed when tassel removal occurred. On the other hand, there are some indicatives that detasseling may increase hormones availability for corn ear growth and development, since the tassel dominates the ears and limits grain yield, what could be observed in hybrids submitted to detasseling (Moreira et al., 2010).

The linear correlation among the measured characters (Table 3) demonstrated significance to the $t$ test for many indispensable associations, where it was evidenced positive tendencies between NLE with MEF, MED, TY, MTS, SYC and SCC. These associations indicates that the increase of leaves magnitude above reminiscent ears, after the mechanical detasseling, potentiate the production attributes of hybrid maize seeds. It happens, in parts, due to the preservation of more leaves in the dossal that beneficiate the plants photosynthetic ability and assimilates production, culminating in the direction of these reserve structures for the plant 
reproductive structure, where beneficiate the dimensions of ears and seeds (Szareski et al., 2018; Rosa et al., 2018). The same conclusion could be found when studying tassel removal isolated and tassel removal plus leaf removal where, for some inbreds the best result was obtained when preserving more leaves (Hunter et al., 1973).

Table 3. Linear correlation to the main measured attributes: Number of leaves above ear (NLE), Humidity of seeds at harvest (HSH), Humidity of seeds after drying (HSD), Mass of ears harvested at production field (MEF), Mass of ears after drying (MED), Thrashing yield (TY), Mass of thrashed seeds (MTS), Seed yield at pre-cleaning (SYC), Seeds cleaned for classification (SCC), Thousand seeds mass (TSM).

\begin{tabular}{lccccccccc}
\hline & HSH & HSD & MEF & MED & TY & MTS & SYC & TSM & SCC \\
\hline NLE & 0.045 & 0.18 & $0.49^{*}$ & $0.65^{*}$ & $0.49^{*}$ & $0.72^{*}$ & $0.75^{*}$ & -0.01 & $0.79^{*}$ \\
HSH & & -0.23 & -0.07 & -0.01 & 0.11 & 0.01 & 0.19 & 0.23 & 0.05 \\
HSD & & & -0.05 & -0.05 & 0.15 & -0.01 & -0.05 & 0.05 & -0.01 \\
MEF & & & & $0.79 *$ & 0.06 & $0.74^{*}$ & 0.24 & -0.19 & $0.72^{*}$ \\
MED & & & & & 0.18 & $0.97 *$ & 0.33 & -0.1 & $0.94^{*}$ \\
TY & & & & & & 0.41 & $0.46^{*}$ & -0.06 & $0.47^{*}$ \\
MTS & & & & & & & 0.39 & -0.09 & $0.98^{*}$ \\
SYC & & & & & & & -0.08 & $0.54^{*}$ \\
TSM & & & & & & & -0.1 \\
\hline
\end{tabular}

*Significant at $5 \%$ by $\mathrm{t}$ test.

There was a positive correlation of MED with MEF and MTF. The same result was identified to MEF with MED. The seeds yield at pre-cleaning was associated with thrashing yield. The SCC were potentiated by MEF, MED, TY, MTS and SYC, in this context, the increase in the seeds mass obtained in field ponders the proportions of cleaned seeds and the yield of the seeds processing unit (Table 3). The TSM did not associated with the measured characters, and general tendencies can be observed (Figure 2) in the casual diagram of linear correlations elaborated through the correlation coefficients.

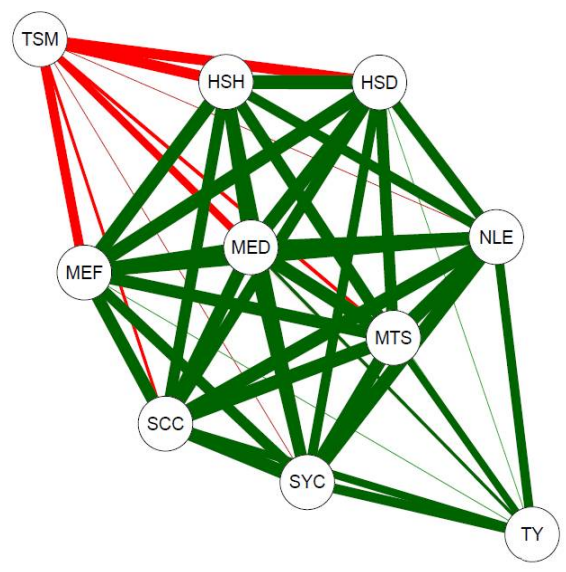

Figure 2. Causal diagram based on the linear correlation coefficients for the interest attributes, the thickness of the line reveals the magnitude of the association among the characters, green coloring (positive correlations) and red coloring (negative correlation). Number of leaves above ear (NLE), Humidity of seeds at harvest (HSH), Humidity of seeds after drying (HSD), Mass of ears harvested at production field (MEF), Mass of ears after drying (MED), Thrashing yield (TY), Mass of thrashed seeds (MTS), Seeds yield at pre-cleaning (SYC), Seeds cleaned for classification (SCC), Thousand seeds mass (TSM). 
The relative contribution of the characters obtained by Singh method (1981) showed (Figure 3 ) that the characters TSM (12.14\%) and SYC (11.09\%) are determinant to differentiate in a multivariate way the mechanical detasseling methods, being necessary more attention during the measurements for these attributes, because of their elevated variability expression. The multivariate analysis of the main compounds revealed that the first component represents $70.23 \%$ and the second $29.76 \%$, in front of these facts is possible to represent, thru these compounds, almost the total variation existent in this study. The dispersion of the characters determines that the detasseling method (Figure 4) by C2P specifically influence the NLE, MEF, MED, SCC and MTS.

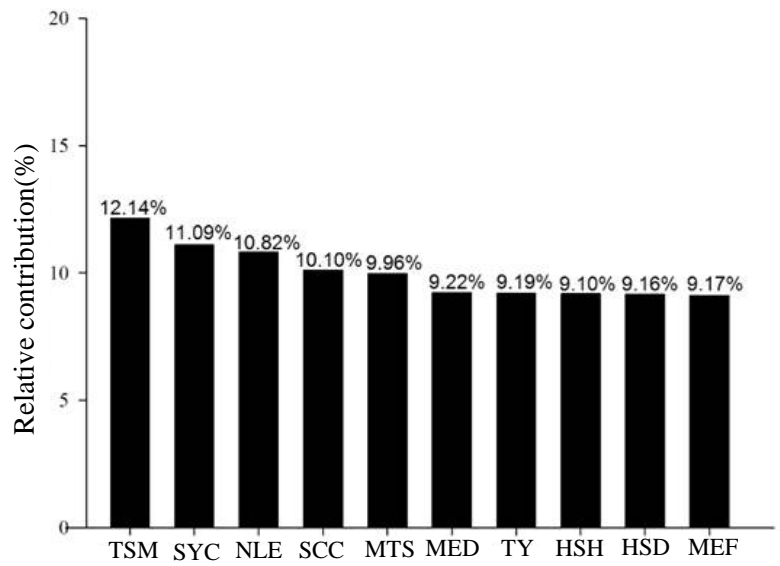

Figure 3. Relative contribution obtained by the Singh (1981) method for the characters: Number of leaves above ear (NLE), Humidity of seeds at harvest (HSH), Humidity of seeds after drying (HSD), Mass of ears harvested at production field (MEF), Mass of ears after drying (MED), Thrashing yield (TY), Mass of thrashed seeds (MTS), Seed yield at pre-cleaning (SYC), Seeds cleaned for classification (SCC), Thousand seeds mass (TSM).

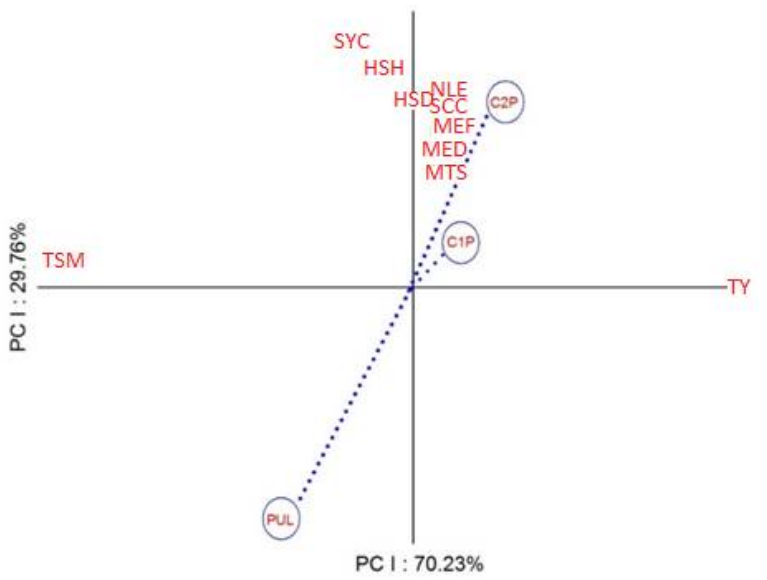

Figure 4. Main compounds Biplot analysis to define the multivariate tendencies of the treats (PUL: "Puller", C1P: "Cutter 2x + Puller", C2P: "Cutter+ Puller") of mechanical detasseling based on the characters, Number of leaves above ear (NLE), Humidity of seeds at harvest (HSH), Humidity of seeds after drying (HSD), Mass of ears harvested at production field (MEF), Mass of ears after drying (MED), Thrashing yield (TY), Mass of thrashed seeds (MTS), Seeds yield at pre-cleaning (SYC), Seeds cleaned for classification (SCC), Thousand seeds mass (TSM). 
The detasseling culminates in stress conditions to the maize plant, since there is removal of the male inflorescence and some superior leaves that significantly contributes to the production of assimilates by the plant. The stress effect caused by the removal of leaves depends on the period in which it occurs, since it determines the growth, development, and metabolic and photosynthetic adjusts of the plant (Wilhelm et al., 1995). The ability of answer of the genotype to the stress caused by the process of leaves removal simultaneously with the mechanical removal of the tassel entails in decrease of seed yield, and influences the physical attributes of seeds and the efficiency of the beneficiation process of hybrid maize seeds.

\section{CONCLUSIONS}

The mechanical detasseling method based on one operation of Cutter and one operation by the Puller method is recommended, since it minimizes costs, reducing transfer and genetic contamination as well, and it potentiates the production of hybrid maize seeds per plant and unit area.

\section{CONFLICTS OF INTEREST}

The authors declare no conflict of interest.

\section{REFERENCES}

Alvim KRDT, Brito CHD, Brandão AM, Gomes LS, et al. (2010). Quantification of leaf area and defoliation effect in corn crop components. Ciênc. Rural. 40: 1017-1022.

Associação Brasileira De Sementes E Mudas - ABRASEM. Estatísticas. < http://www.abrasem.com.br/site/estatisticas/ >. Accessed July 12, 2019.

Baretta D, Nardino M, Carvalho IR, Pelegrin AJ, et al. (2017). Estimates of genetic parameters and genotypic values prediction in maize landrace populations by REML/BLUP procedure. Genet. Mol. Res. 16: gmr16029715.

Brasil. Ministério da Agricultura, Pecuária e Abastecimento. (2009). Regras para análise de sementes. Ministério da Agricultura, Pecuária e Abastecimento. Secretaria de Defesa Agropecuária. Brasília, DF: Mapa/ACS, 395p.

Carvalho IR, Nardino M, Demari GH, Pelegrin AJ, et al. (2017). Components of variance and inter-relation of important traits for maize (Zeamays) breeding. J. Agr. Sci. 11: 982-988. 10.21475/ajcs.17.11.08.pne474.

Carvalho IR, Nardino M, Pelegrin AJ, Ferrari M, et al. (2016). Path analysis and Annicchiarico method applied in relation to protein in corn grains. Aust. J. Basic Appl. Sci. 10: 300-306.

CONAB - (2017) Companhia Nacional De Abastecimento. Acompanhamento de safra brasileira de grãos, safra 2017/2018. https://www.conab.gov.br/info-agro/safras/graos. Accessed July 12, 2019.

Dias CRP (2015). Influência do despendoamento e da eliminação de plantas dominadas na qualidade de sementes e na produtividade de milho. Master's Thesis. Faculdade de Agronomia e Medicina Veterinária, Universidade de Brasilia, Brasilia, DF, Brazil.

Hunter RB, Mortimore CG and Kannenberg LW (1973). Inbred Maize Performance Following Tassel and Leaf Removal. Agron. J. 65: 471-472. doi:10.2134/agronj1973.00021962006500030035x.

Komatuda AS, Santos CM, Santana DG, Souza MA, et al. (2006). Effects of detasseling methodologies on yield and quality of hybrid maize seed. Rev. Bras. Milho Sorgo. 5(3): 359-368.

Magalhães PC, Durães FOM, Oliveira AC and Gama EEG (1999). Effects of different detasseling practices on maize yield. Sci. Agric. 56(1): 77-82.

Moreira JN, Silva PSL, Silva KMB, Dombroski JLD, et al. (2010). Effect of detasseling on baby corn, green ear and grain yield of two maize hybrids. Horitc. Bras. 28: 406-411.

Nardino M, Carvalho IR, Barros WS, Souza VQ, et al. (2016). Diallel Cross analysis in maize. Int. J. Cur. Res. 8: 3568635692.

Nardino M, Baretta D, Carvalho IR, Olivoto T, et al. (2018). Environment Stratification in the Evaluation of Corn Hybrids in Southern Brazil. J. Agr. Sci. 10: 333.DOI: 10.5539/jas.v10n10p333.

Pereira FH (2007). Influência do despendoamento e da desfolha na produção e qualidade de sementes de milho. Master's Thesis. Universidade Estadual Paulista, Jaboticabal, SP, Brazil. 
Rosa TC, Carvalho IR, Szareski VJ, Pelegrin AJ, et al. (2018). Agronomic Performance and Multivariate Analysis Applied to Three-Waycross Maize Hybrids. J. Agr. Sci. 10: 319 -328.

Sangoi L and Salvador RJ (1998). Effect of maize plant detasseling on grain yield, tolerance to high plant density and drought stress. Pesq. agropec. Bras. 33: 677-684.

Sing RP and Nair KPP (1975). Defoliation studies in hybrid maize. I. Grain yield, quality and leaf chemical composition. J. Agr. Sci. 85(2): 241-245. https://doi.org/10.1017/S0021859600062031.

Szareski VJ, Carvalho IR, Kehl K, Levien AM, et al (2018). Evaluation of the adaptability and stability of wheat genotypes using a phenotypic index of seed vigor. Pesq. Agr. Bras. 53: 727-735.

Szareski VJ, Carvalho IR, Kehl K, Pelegrin AJ, et al. (2018). Interrelations of Characters and Multivariate Analysis in Corn. J. Agr. Sci. 10: 187-194. 10.5539/jas.v10n2p187.

Szareski VJ, Carvalho IR, Kehl K, Levien AM, et al. (2018). Wheat seeds yield in Brazil: Phenotypic and predicted genetic approaches for genotype ranking. Genet. Mol. Res, 17: gmr18026.

Uitzil AMP, Souza VQ, Olivoto T, Nardino M, et al (2016). Yield components of hybrid based on the plant population and artificial defoliation. Aust. J. Basic Appl Sci. 10: 136-142.

Wilhelm WW, Jonhnson BE and Schepers JS (1995). Yields, quality, and nitrogen use of inbred corn with varying numbers of leaves removed during detasseling. Crop Sci. 35: 209-212. doi:10.2135/cropsci1995.0011183X003500010039. 